IJLR: International Journal of Law Recontruction

Volume 5, Number 1, April 2021

DOI : http://dx.doi.org/10.26532/ijlr.v5i1.15587

\title{
THE CRIMINAL RESPONSIBILITY BY CORPORATE
}

\author{
Dwi Wahyono \\ Sultan Agung Islamic University \\ dwiwahyono@unissula.ac.id
}

\begin{abstract}
Corporation is the subject of a criminal act. In Indonesia, the statutory regulations that initiated the placement of corporations as subjects of criminal acts and which can be directly accounted for are Act No. 7 the Emergency of 1955 concerning Investigation, Prosecution and Economic Criminal Justice, as subjects of criminal law corporations do not have an inner attitude. Meanwhile, to be criminally accountable, a men's rea/schuld is required. Crimes committed by corporations are very detrimental to society and the state. Meanwhile, the conventional accountability system which is individual, direct, and based on schuld, is difficult to apply to corporations. The purpose of writing is to analyze the corporate liability system to impose crimes against corporations, and obstacles to imposing crimes against corporations. The method used is the statute approach (legal approach) and the case approach (case approach), the analysis method uses qualitative analysis with interpretation, and the data collection method uses library research. It can be concluded that corporations can be held accountable by using a system of absolute and substitute liability, and the obstacle is the application of a conventional criminal liability system and the difficulty of proving corporate wrongdoing. It is suggested that there is a common perception between law enforcers about the criminality of corporations.
\end{abstract}

Keywords: Emergency Act No. 7 of 1955; Corporation; Criminal Liability.

\section{A. INTRODUCTION}

Indonesia is a constitutional state based on Pancasila and the 1945 Constitution, which regulates all life of Indonesian society. The law here has a very important meaning in the aspects of life as a guide for human behavior in relation to other humans. ${ }^{1}$ The existence of the corporation as one of the legal subjects has contributed greatly to the economic growth and development of a country, without exception in Indonesia. But on the other hand the existence of the corporation has become a tool for several criminal acts that have an impact on the country through corporate criminal acts. $^{2}$

1 Fines Fatimah, \& Barda Nawawi Arief, Pertanggungjawaban Pengganti (Vicarious Liability) dalam Kebijakan Formulasi Hukum Pidana Di Indonesia, Jurnal Law Reform, Vol.7, (No.2) 2012, page.1-43.

2 Herlina Manullang, Meminta Pertanggungjawaban Pidana Perusahaan Induk Atas Perbuatan Tindak Pidana Lingkungan Hidup Yang Dilakukan Oleh Anak Perusahaan, Samudra Keadilan, Volume 15, Nomor 1, January-June 2020, page.112-115 
The current Criminal Code is a legacy of the Dutch Government, which has been in effect since 1918. After Indonesia's independence in 1945 based on Article II of the Transitional Rules of the 1945 Constitution, the Criminal Code is declared to remain valid throughout Indonesia to fill in legal vacuum, and adjusted to the condition of Indonesia after independence by Act No.1 of 1946 in conjunction with Act No. 73 of 1958. Literal criminal responsibility, Criminal liability contains the principle of error (principle of culpability), which is based on a monodualistic balance that the principle of error based on the value of justice must be aligned paired with the principle of legality based on the value of certainty. Criminal responsibility is a mechanism to determine whether an accused or suspect is responsible for a criminal act that has occurred or not. In order for the perpetrator to be convicted, it is required that the criminal act he has committed fulfills the elements stipulated in the law. ${ }^{3}$

The Criminal Code often lags behind the development of crimes that occur in society so that it must be patched up to keep up with these developments. As a result, a law was born that changed and added to the Criminal Code. Even so, the Criminal Code still lags behind the development of crime because it is in addition to the law which partially amends and adds to the Criminal Code, a criminal law that is spread outside the Criminal Code or what is called a special criminal law such as Act No. 31 of 1999 concerning Eradication of Corruption is also made, in conjunction with Act No. 20 of 2001 concerning Amendments to Act No. 31 of 1999 concerning Eradication of Corruption Crime.

Forming a special criminal law must meet certain criteria as stated by Loebby Loqman. Special crimes must meet certain criteria as proposed by Loebby Loqman, ${ }^{4}$ that an act must be regulated separately in a special criminal law because:

1. If it is entered into the codification it will damage the codification system;

2. Due to certain circumstances such as emergencies; and

3. Due to the difficulty of making changes or additions to the codification, because in certain cases it is desirable that there are deviations from the pre-existing system.

From the aforementioned criteria connected with Act No. 31 of 1999 in conjunction with Act No. 20 of 2001, it is known that there are special matters in the Law that are different from the Criminal Code. Between them are corporate problems as subjects of criminal law, where corporations can commit criminal acts and can be held accountable. So the Law of Corruption Crime cannot be included in the Criminal Code because the special things regulated in the Eradication of Corruption Crime will change the Criminal Code system.

Indonesian criminal law has recognized corporations as subjects of criminal law since the existence of Emergency Act No. 17 of 1951

3 Abdurrakhman Alhakim, Eko Soponyono, Kebijakan Pertanggungjawaban Pidana Korporasi Terhadap Pemberantasan Tindak Pidana Korupsi, Jurnal Pembangunan Hukum Indonesia, Volume 1, Nomor 3, Tahun 2019, page.322-336

4 Loebby Luqman, Delik Politik di Indonesia, Ind-Hill-Co, 1993, page 111. 
concerning Stockpiling of Goods, and Act No. 7 of Emergency 1955 concerning Economic Crime. However, the Criminal Code does not explicitly regulate the responsibility of corporations as perpetrators of criminal acts. ${ }^{5}$

Corporations as perpetrators of crimes are better known as "corporate crime" or "corporate criminal acts", namely crimes or crimes committed by the corporation. The corporation as perpetrators of criminal acts have experienced several legal developments, namely:

1. The corporation cannot commit a crime and cannot be accounted for criminally. At this stage, the crime carried out by the corporation is limited to individuals (natural humans or naturlijk person). If a crime occurs in the corporation environment, the crime is considered by the corporate management. ${ }^{6}$

2. Corporations can commit criminal acts, but cannot be accounted for criminally. At this stage criminal liability can be requested for administrators who actually lead the corporation. Therefore, the corporation is recognized by being able to commit a crime but the party that is responsible for its criminal actions is its members or managers, as long as they are expressly declared in laws and regulations, as long as they are expressly declared in laws and regulations in the relevant corporate rules. Thus at this stage, the corporate criminal accountability has not yet ${ }^{7}$

3. Corporations can commit criminal acts and can be accounted for criminally. At this stage the corporation is considered to be able to commit a criminal act and account for his actions criminally. The reason is regulated by the Corporation as a criminal act of a crime as well as a party that must be responsible for his actions criminally because in Economic Crimes and non-fiscal criminals, the benefits obtained by corporations or losses suffered by the community can be so large, so that it will not be balanced Only imposed on its corporations, no or no guarantee that the corporation will not repeat the crime or crime. Corporate chance with the type and weight that is in accordance with the properties of the corporation, is expected to force the corporation to obey the relevant regulations. ${ }^{8}$

Corporate Criminal Accountability in General Provisions Criminal Law, at this stage, the regulation on the accountability of corporate crimes is no longer spread outside the Criminal Code (hereinafter referred to as the Criminal Code). This arrangement is still a Ius constituendum, namely regulating a corporate criminal accountability system in general in the National Code I book, so that it will apply to all types of criminal acts. ${ }^{9}$

5 Warih Anjani, Pertanggungjawaban Korporasi Sebagai Pelaku Tindak Pidana, Ilmiah Widya Yustisia Journal, Volume 1, Number 2, 2016, page, 120

6 Muladi and Dwidja Priyatna, Pertanggungjawaban Korporasi Dalam Hukum Pidana, STHB, Bandung, 1991, page.52

7 Ibid.

8 Dwidja Priyatno, Kebijakan Legislasi Tentang Sistem Pertanggungjawaban Pidana Korporasi diIndonesia, CV Utomo, Bandung, 2003, page. 27

9 Kristian, Kejahatan Korporasi di Era Modern dan Sistem Pertanggungjawaban Pidana Korporasi, Refika Aditama, Bandung, 2016, page. 174 
The spirit of eradicating corruption after the Reformation was marked by the creation of various legislative products as follows: ${ }^{10}$

1. Decree of the People's Consultative Assembly Number XI/MPR/1998 concerning "The Implementation of a State that is Clean and Free of Corruption, Collusion and Nepotism";

2. Act No. 28 of 1999 concerning "State Administration that is Clean and Free from Corruption, Collusion and Nepotism";

3. Act No. 31 of 1999 concerning "Eradication of Corruption Crime", which amends and replaces the old law (Act No. 3 of 1971). Also Act No. 15 of 2002 concerning the Crime of Money Laundering, Act No. 30 of 2002 concerning the Corruption Eradication Commission. And in the planning, namely the legislation on the Acceleration of Corruption Eradication and the Law on Protection of Witnesses against criminals.

\section{B. RESEARCH METHODS}

In writing this journal using normative juridical research methods, using secondary data, and data from journals that have been published then further analyzed by literature study. The normative juridical approach is an approach that refers to the prevailing laws and regulations. ${ }^{11}$ Legal research with a normative doctrinal approach, or normative juridical legal research or normative legal research is basically an activity that examines the internal aspects (to solve problems that exist in) the internal of positive law. This is done as a consequence of the view that law is an autonomous institution that does not have any relationship with other social institutions. ${ }^{12}$

\section{RESULT AND DISCUSSION}

\section{Corporate Criminal Liability System}

The corporation is referred to as a legal personality which means that corporations can have wealth as humans and can demand and are prosecuted in civil cases. But in its development there arises to account for corporations in criminal cases even though criminal can be imposed on corporations are usually criminal fined or in the form of other actions, such as acts of rules or administrative actions. The understanding of the corporation as a subject of law in the Indonesian criminal law system can be distinguished between who commit a criminal act (maker) and responsible. ${ }^{13}$

The corporation has been used as a subject of criminal acts whose application has been legitimized and is justified by several doctrines or theories including: identification theory, strict liabilities theory (strict

10 Barda Nawawi Arief, Kapita Selekta Hukum Pidana, Bandung, Citra Aditya Bakti, 2006, page 65-66.

11 Bambang Sunggono, Metodologi Penelitian Hukum, PT Raja, Jakarta, 2003, page. 32.

12 Kornelius Benuf, Muhamad Azhar, Metodologi Penelitian Hukum sebagai Instrumen Mengurai Permasalahan Hukum Kontemporer, Jurnal Gema Keadilan, Volume 7 Edisi I, June 2020, page.20-33

13 Rainma Rivardy Rexy Runtuwene, Pertanggungjawaban Pidana Korporasi Sebagai Suatu Perkembangan Tindak Pidana, Lex et Societatis, Vol. V/No. 2/March-April/2017.page.124131 
accountability theory according to law), Vicarious Liability Doctrine (theory or doctrine of responsibility), The Corporate Culture Model or Company Culture Theory, Doctrin of Aggregation and Reactive Corporate Fault. ${ }^{14}$

a. Corporations as makers and also responsible

In this system of accountability, there has been a shift in view, that corporations can be accounted for as makers, in addition to natural humans (natuurlijk person). So rejection of corporate punishment based on the doctrine of the Non-Potest Delinquere University has undergone a change by accepting the concept of functional actors. ${ }^{15}$

So in this accountability system is the direct initiation of responsibility from the corporation. As for the things that can be used as justification that the corporation as the maker and at the same time is responsible is as follows: First, because in various economic and fiscal crimes, the profits obtained by the corporation or the losses suffered by the community can be so great that it will not be balanced if the punishment is imposed only on the management. Second, by only criminalizing the management, there is no guarantee that the corporation will not repeat the crime again. By punishing a corporation with the type and weight according to the nature of the corporation, it is hoped that the corporation can comply with the relevant regulations. ${ }^{16}$

In Indonesia, the laws and regulations that initiated the placement of corporations as subjects of criminal acts and which can be directly accounted for is Act No. 7 Drt of 1955 concerning Investigation, Prosecution, and Economic Crime Trial, especially in Article 5 paragraph (1) which reads: "If an economic crime is committed by or on behalf of a legal entity, a company, an association of other people or a foundation. , then criminal charges are filed and criminal penalties and disciplinary measures are imposed on the legal entity, company, association, or foundation, whether against those who give orders to commit the economic crime, act as a leader in the act or omission or both".

The next development is the birth of various statutory rules outside the Criminal Code, which regulates similar matters, for example, Article 39 of Act No. 3 of 1989 concerning Telecommunications, Article 24 of Act No. 2 of 1992 concerning Insurance Business, Article 20 of Act No. 31 of 1999 concerning Corruption Crimes. and others.

14 Kristian, Penerapan Sistem Pertanggungjawaban Pidana Bagi Lembaga Perbankan Ditinjau Dari Sistem Pertanggungjawaban Pidana Korporasi, Syiar Hukum Jurnal Ilmu Hukum, Volume 17 Nomor 2 2019, page.114-142

15 Setiyono, Kejahatan KorporasiAnalisis Viktimologi dan Pertanggungjawaban Korporasi Dalam Hukum Pidana, Edisi Kedua Cetakan Pertama, Malang, Banyu Media Publishing, 2003, page 16

16 Ibid., page 15 
In connection with the acceptance of corporations as perpetrators of criminal acts and being accountable, then speaking of corporate criminal liability there are several doctrines regarding corporate criminal responsibility, including:

1) Identification Doctrine;

According to this doctrine, criminal responsibility, the principle of "mens rea" is not ruled out, where according to this doctrine the mental actions or attitudes of senior corporate officials who have a "directing mind" can be considered as corporate attitudes. This means that the mental attitude is identified as a corporation, and thus the corporation can be directly accounted for. ${ }^{17}$ The action or will of the director is an act. and the will of the corporation. ${ }^{18}$ This accountability differs from vicarious liability and strict liability, wherein this identification doctrine, the principle of "mens rea" is not ruled out, whereas, in the vicarious liability and strict liability doctrines, the principle is not required. "Mens rea", or the principle of "mens rea" does not apply absolutely. ${ }^{19}$

2) The doctrine of vicarious liability;

Substitute liability is someone's responsibility without personal fault, taking responsibility for the actions of others. ${ }^{20}$

3) Doctrine of Strict Liability According to the Law (strict liability)

The principle of absolute responsibility without having to prove whether or not there is an element of guilt in the perpetrator of the crime. This criminal liability is known as strict liability crimes. ${ }^{21}$

b. When the Corporation Commits a Crime

Talking about this, according to Barda Nawawi Arief, ${ }^{22}$ In the special rules of criminal law scattered outside the KHUP, which recognize corporations as subjects of criminal law, there is no uniformity in their regulations, meaning that some formulate and some do not.

Specific provisions governing when a corporation commits a criminal act, for example, Act No. 7 Drt of 1955. This is regulated in Article 15 paragraph (2) which reads: "An economic crime is also committed by $a$, on behalf of a legal entity, a company. , an association of people, or a foundation, if the action is carried out by people either based on a working relationship or other relationship,

17 Muladi, Penerapan Pertanggungjawaban Korporasi Dalam Hukum Pidana, Fakultas Hukum Undip, Semarang, 2004, page, 21

18 Hanafi, Reformasi Sistem Pertanggungjawaban Pidana, Hukum Journal, Volume, 6 Number 2, 1999, page 17

19 Dwidja Priyatno, Pertanggungjawaban Korporasi Dalam Hukum Pidana, Sekolah Tinggi Hukum, Bandung, 1991, page 93-94

20 Ibid., page 53

21 Romli Atmasasmita, Perbandingan Hukum Pidana Cetakan I, Mandar Maju, Bandung, 1996, page 76

22 Barda Nawawi Arief, Op. Cit., 2003, page 230 
acting within the legal entity, company, association or foundation does not care whether the individual individuals have committed a criminal offense economy or in them together there are elements of the crime".

In connection with the aforementioned formulation, Barda Nawawi Arief said: In the formulation of Article 15 paragraph (2) Economic Crime, there is a formulation that "seems" to explain when a legal entity is said to have committed a criminal act. The formulation reads "a criminal act is also committed by or on behalf of a legal entity and so on". Given the words "also done" it is clear that the above formulation is only a fiction that expands the form of a criminal act that is not committed by a legal entity but is "considered" to have been committed by a legal entity. So the above formulation does not explain the definition of when a legal entity is said to have committed (as the maker) a criminal act. ${ }^{23}$

In the elucidation of Article 15 of the Law on Economic Crimes (Act No. 7 Drt/1955) which, between other things, reads: "Paragraph 2 determines in which cases an economic crime is deemed to have been committed by a legal entity. ${ }^{24}$ After seeing the formulation of Article 15 paragraph (2) and the explanation it turns out that has not confirmed the limits or measures used to determine that an economic crime is committed by a legal entity or corporation. It's just that it says the limit or size is mentioned, namely:

1) based on a working relationship or other relationship; and

2) acting within a legal entity environment.

So a criminal act of corruption is deemed to have been committed by a corporation if the criminal act is committed by persons:

1) based on a working relationship or other relationship;

2) acting in a corporate environment;

3) either alone or together. ${ }^{25}$

\section{Constraints on Imposing Crime Against Corporations}

In the Indonesian Legal System a form of certain actions (Actus Reus or Guilty ACT) and proof of the Mens Rea element of an abstract entity such as the corporation so that it can be attributable to being very difficult. Even though it makes the law a legal basis for the charged criminal liability of the corporation, but until now the rules are reluctant to be used by the court. This can be proven from the absence of a corporation dragged in the future of the court in the case of traffic accidents and of course this impacts the court's decision on this matter

23 Muladi, Barda Nawawi Arief, Teori-teori dan Kebiakan Hukum Pidana, Edisi Revisi, Alumni, Bandung, 1992, page 134

24 Dwidja Priyatno, Op. Cit., page 174

25 Barda Nawawi Arief, Op. Cit., page 209 
becomes non-existent. $^{26}$

Criminal accountability when someone is said to have an error. Even though the mistake in question is the situation of the soul of someone who committed the deeds and actions taken in such a way, so that the person should be denounced. Criminal will remain imposed if the actor does indeed have an error in committing a crime. Conversely, even though it has committed an act that is prohibited and the action is threatened with a criminal subject of criminal acts that have no mistakes, will not be sentenced to be sentenced. This means that the principle of prison without an error is placed as a fundamental principle in the accountability of criminal acts because it has committed a crime. In the context of its own error consists of several aspects, which are only attached to humans, namely, the ability to be responsible, intentional, negligence, and there is no reason for forgiving. Therefore, elements of responsible abilities and intentional elements can be met by humans as individual subjects. Thus the criminal accountability will be difficult to be imposed on corporations, because it is difficult to wear elements of errors to corporations that are not humans. As a legal entity, the corporation has no soul. Besides that it is also difficult to prove the intention and size of corporate maturity and to determine the wishes and skills. ${ }^{27}$

The criminal responsibility system adopted in Indonesia is based on mistakes. Mistakes are the criminal's inner attitude. Mistakes only exist in natural human legal subjects. The corporation does not allow an inner attitude. Meanwhile, the principle of nulla poena sine culpa must still be obeyed to answer the perpetrators of criminal acts. Therefore, it is not easy to prove that there are mistakes in corporations or legal entities. ${ }^{28}$ Because corporations are not natural legal subjects that do not have a mens rea.

Corporations can be criminally liable because the crimes committed by the corporation have a big loss on society, the environment, and the state. Some corporate cases are not only used as a means of committing the crime but are used as a means of accommodating the proceeds of crime so that the corporation can benefit from the proceeds of crime. This can be observed in several cases, for example, the case of PT Asian Agri Group tax evasion. The perpetrator, in this case, committed tax evasion by submitting an incorrect tax return so that the state finances were IDR1,259,977,695,652 or approximately IDR1.26 Trillion. (Decision of the Supreme Court of the Republic of Indonesia Number

26 Ratna Kumala Sari, Nyoman Serikat Putra Jaya, Pertanggungjawaban Pidana Perusahaan Teknologi atas Tindak Pidana Kecelakaan Lalu Lintas oleh Pengemudi Ojek Online, Udayana Master Law Journal, Vol. 8 No. 1 May 2019, page.34-48

27 Mahulae, H. P. I., \& Pujiyono, U. R. (2017). Tinjauan Yuridis Pertanggungjawaban Pidana Korporasi Dalam Kecelakaan Lalu Lintas serta Konsep Penegakan Hukumnya Ditinjau Berdasarkan Undang-undang Nomor 22 Tahun 2009 tentang Lalu Lintas dan Angkutan Jalan, Diponegoro Law Journal. 6(2), h. 1-11

28 Barda Nawawi Arief, Masalah penegakan Hukum dan Kebijakan Hukum Pidana Dalam Penanggulangan Kejahatan, Kencana, Jakarta, 2014, page117 
2239K/Pid.Sus/2012). ${ }^{29}$

The empirical condition of the impact of crimes committed by corporations strengthens the theory of identification and theory of functional actors and other theories that legitimize corporate responsibility; at the same time weakens the doctrine that corporations cannot be convicted (University Delinquere non potest). Even identification theory and functional actor theory (fuctionele dader) have been used in the international community especially against criminal acts related to the management of natural resources, export and import, banking, and taxation. ${ }^{30}$

Indonesian criminal law has recognized corporations as subjects of criminal law since the existence of Emergency Act No. 17 of 1951 concerning Stockpiling of Goods, and Act No. 7 of Emergency 1955 concerning Economic Crime (Wet Economic Delichten). However, the Criminal Code does not explicitly regulate the responsibility of corporations as perpetrators of criminal acts. Although in other areas of law, namely civil law, civil law subjects other than people have been recognized, namely corporations. Therefore, in practice, law enforcers have different interpretations of corporations. ${ }^{31}$

The complexity of corruption crimes committed by corporations is also related to how law enforcers apply sanctions against criminal acts of corruption that have been formally stipulated by the $\mathrm{DPR}^{32}$ namely:

a. The main criminal penalty in the form of a fine is not maximal so that it is not effective in ensnaring and giving a deterrent effect to the perpetrators of corruption;

b. Additional criminal penalties in the form of complete or partial closure of the company for a maximum period of 1 (one) year as stipulated in Article 18 paragraph (1) letter c, must be considered because it can have an impact on social unrest in the community and affect the performance of the government in the manpower sector; and

c. The Criminal Procedure Code has not regulated the provisions on corporate criminal procedures.

\section{CONCLUSION}

The corporate liability system as a criminal offender follows the general criminal law liability system, which is based on error. However, because corporations are legal subjects that cannot have errors, an accountability system is implemented that is not based on absolute error. The accountability system referred to is Strict Liability, Vicarious Liability, and Identification theory/doctrine, and delegation theory.

29 Warih Anjani, Pertanggungjawaban Korporasi sebagai Pelaku Tindak pidana, Widya Yustisia Journal, Volume 1 Number 2, 2016, page 120

30 Ibid.

31 Ibid.,

32www.pnmedankota.go.id/main/index.php/tentang-pengadilan/profilpengadilan/sejarahpengadilan/384-kendalapenerapan-sanksi-pidana-terhadap-korporasisebagaipelaku-tindak-pidana-korupsi, acceded on 29 October 2020 
Constraints in imposing criminal offenses against corporations are: Application of an individual, direct, and based on schuld system of accountability; Proof of corporate wrongdoing is very difficult; there is no regulation on corporations as the subject of criminal acts in both material criminal law and formal criminal law.

\section{BLIBIOGRAPHY}

\section{Books:}

Bambang Sunggono, 2003, Metodologi Penelitian Hukum, PT Raja, Jakarta;

Barda Nawawi Arief, Kapita Selekta Hukum Pidana, Bandung, Citra Aditya Bakti, 2006;

Barda Nawawi Arief, 2014, Masalah penegakan Hukum dan Kebijakan Hukum Pidana Dalam Penanggulangan Kejahatan, Kencana, Jakarta;

Dwidja Priyatno, 1991, Pertanggungjawaban Korporasi Dalam Hukum Pidana, Sekolah Tinggi Hukum, Bandung;

Dwidja Priyatno, 2003, Kebijakan Legislasi Tentang Sistem Pertanggungjawaban Pidana Korporasi diIndonesia, CV Utomo, Bandung;

Loebby Luqman, 1993, Delik Politik di Indonesia, Ind-Hill-Co;

Kristian, 2016, Kejahatan Korporasi di Era Modern dan Sistem Pertanggungjawaban Pidana Korporasi, Refika Aditama, Bandung;

Muladi and Dwidja Priyatna, 1991, Pertanggungjawaban Korporasi Dalam Hukum Pidana, STHB, Bandung;

Muladi and Barda Nawawi Arief, 1992, Teori-teori dan Kebiakan Hukum Pidana, Edisi Revisi, Alumni, Bandung;

Muladi, 2004, Penerapan Pertanggungjawaban Korporasi Dalam Hukum Pidana, Fakultas Hukum Undip, Semarang;

Romli Atmasasmita, 1996, Perbandingan Hukum Pidana Cetakan I, Mandar Maju, Bandung;

Setiyono, 2003, Kejahatan KorporasiAnalisis Viktimologi dan Pertanggungjawaban Korporasi Dalam Hukum Pidana, Edisi Kedua Cetakan Pertama, Banyu Media Publishing, Malang;

\section{Journals:}

Abdurrakhman Alhakim, Eko Soponyono, Kebijakan Pertanggungjawaban Pidana Korporasi Terhadap Pemberantasan Tindak Pidana Korupsi, Jurnal Pembangunan Hukum Indonesia, Volume 1, Nomor 3, Tahun 2019; 
Fines Fatimah, \& Barda Nawawi Arief, Pertanggungjawaban Pengganti (Vicarious Liability) dalam Kebijakan Formulasi Hukum Pidana Di Indonesia, Jurnal Law Reform, Vol.7, (No.2) 2012;

Hanafi, Reformasi Sistem Pertanggungjawaban Pidana, Hukum Journal, Volume, 6 Number 2, 1999;

Herlina Manullang, Meminta Pertanggungjawaban Pidana Perusahaan Induk Atas Perbuatan Tindak Pidana Lingkungan Hidup Yang Dilakukan Oleh Anak Perusahaan, Samudra Keadilan, Volume 15, Nomor 1, January-June 2020;

Kornelius Benuf, Muhamad Azhar, Metodologi Penelitian Hukum sebagai Instrumen Mengurai Permasalahan Hukum Kontemporer, Jurnal Gema Keadilan, Volume 7 Edisi I, June 2020;

Kristian, Penerapan Sistem Pertanggungjawaban Pidana Bagi Lembaga Perbankan Ditinjau Dari Sistem Pertanggungjawaban Pidana Korporasi, Syiar Hukum Jurnal Ilmu Hukum, Volume 17 Nomor 2 2019;

Rainma Rivardy Rexy Runtuwene, Pertanggungjawaban Pidana Korporasi Sebagai Suatu Perkembangan Tindak Pidana, Lex et Societatis, Vol. V/No. 2/March-April/2017;

Ratna Kumala Sari, Nyoman Serikat Putra Jaya, Pertanggungjawaban Pidana Perusahaan Teknologi atas Tindak Pidana Kecelakaan Lalu Lintas oleh Pengemudi Ojek Online, Udayana Master Law Journal, Vol. 8 No. 1 May 2019;

Warih Anjani, Pertanggungjawaban Korporasi sebagai Pelaku Tindak pidana, Widya Yustisia Journal, Volume 1 Number 2, 2016

Warih Anjani, Pertanggungjawaban Korporasi Sebagai Pelaku Tindak Pidana, IImiah Widya Yustisia Journal, Volume 1, Number 2, 2016

\section{Regulations:}

Act No. 17 of 1951 concerning Stockpiling of Goods

Act No. 7 of Emergency 1955 concerning Economic Crime

Act No. 7 Drt of 1955 concerning Investigation, Prosecution, and Economic Crime Trial

Act No. 31 of 1999 concerning Eradication of Corruption is also made, in conjunction with Act No. 20 of 2001 concerning Amendments to Act No. 31 of 1999 concerning Eradication of Corruption Crime

\section{Internet:}

www.pnmedankota.go.id/main/index.php/tentang-pengadilan/profilpengadilan/sejarahpengadilan/384-kendalapenerapan-sanksipidana-terhadap-korporasi-sebagaipelaku-tindak-pidana-korupsi 